\title{
WATER AND FEED UTILIZATION RELATIONSHIP IN WEST AFRICAN DWARF (FORES GOATS OF SOUTHERN NIGERIA
}

\author{
U. J. IKHATUA; T. I. DEDE; AND A. S. APUMAMI \\ Department of Animal Science, University of Benin, Benin, \\ Received 8 June, 1992; accepted 1 December, 1992
}

\begin{abstract}
Eight bucks weighing between 12 and $15 \mathrm{~kg}$ liveweight and age range of $9-12$ months were used in a 42-day feeding and metabolism trials to study the water intake and feed utilization relationship in the West African Dwarf (forest) gonts of Southern Nigeria. There was no significant difference in the average water intake between the groups but feed intake was significantly different between the groups $(P<0.05)$. Feed efficiency was very similar between the groups; Dry Matter (DM) intake to water intake ratios were 0.21 and 0.27 respectively while mean daily liveweight gains were significantly different. Nitrogen utilization showed significantly higher nitrogen intake and nitrogen loss between the groups but nitrogen retained as per cent of nitrogen intake was however not different between the groups. Results from the study established a positive correlation between water intake and feed intake in the experimental goats with correlation (r) values of 0.47 and 0.53 for the two groups respectively.

Key word: Water intake, feed utilization, West African Dwarf Goats.
\end{abstract}

\section{INTRODUCTION}

Water and feed intake are generally associated with each other. (Whyte, 1963, Macfarlane and Howard 1972, Singh et al 1976, King et al. 1978, Preston and Leng (1987), stated that a restriction in water intake apparently reduces feed intake. Philips (1960) explained that the relationship between water and feed intake exists mainly because of the role of water in the process of food digestion, elimination of digested residues as well as in the excretion of waste products of metabolism.

Goats are efficient animals in the use of water (Devendra and McIlroy 1982). In the tropics, goats are adapted to water shortages and often have low water turn over rates (Devendra and Mcllroy, 1982). The efficient conversion of the Dry Matter (DM) intake of goats indicates their capacity to utilize feed voluntarily, usually consuming DM at the rate of $2-3 \%$ of their body weights. A practical knowledge of the relationship between water intake and feed intake/utilization of this breed of goat will provide a guide in the provision of adequate water and feed to other breeds of goats managed in this ecological zone.

This work was undertaken to provide some information on the relationship between water and feed intake and utilization by the West African Dwarf (Forest) goats of the humid environment of southern Nigeria under the semi-intensive system of management.

\section{MATERIALS AND METHOD}

Eight bucks of the WAD (Forest) goats weighing between 12 and $15 \mathrm{~kg}$ liveweight and age range of $9-12$ months were used in a 42day feeding and digestibility trials at the Farm Project site of the University. They were randomly allocated on the basis of liveweight into two treatment groups designated A and B of 4 bucks each. Each buck was maintained in individual feeding pen and was offered $1.5 \mathrm{~kg} /$ day of cowpea hay.

They were routinely fed twice daily at $08.00 \mathrm{~h}$ and $16.00 \mathrm{~h}$ respectively. Bucks in the groups $A$ and $B$ were each provided 5.0 and $7.5 \mathrm{~kg}$ of water per day (ARC, 1965) in half-cut drums. The total amount of water was offered once daily to the goats in the morning. Before new feed and water were offered in the morning to the experimental goats, the residues of the roughage was weighed to determine intake and 
roughage was weighed to determine intake and the water intake was calculated by a measure of the water left. All the goats were weighed at the commencement, the 2nd week and end of the trial. In order to minimize fluctuations in body weights, the mean weights at the commencement and $2 \mathrm{nd}$ week were used to calculate the metabolic size $\left(\mathrm{W}^{0.75} \mathrm{~kg}\right)$ of the goats.

The feeding trial was terminated by a metabolism period of 5 days in which total faecal and urine collections were made by procedure described by Ikhatua and Olubajo (1979). Samples of the roughage fed and the residucs were collected and representative samples were taken for the determination of the chemical constituents. All proximate analyses were determined using A.O.A.C. (1980) methods. All results were subjected to statistical analysis using the student t-test (Steel and Torrie, 1960).

\section{RESULTS AND DISCUSSION}

From the proximate chemical composition of the roughage (Table 1), its crude protein content of $12.7 \%$ is quite higher than that recorded for groundnut haulms $(9.8 \%)$ also a legume hay by Ikhatua and Adu (1984). This high crude protein value of the cowpea hay is indicative of its high feeding value, conforming with the report of Williamson and Payne (1984) that legume straws possess high feeding values.

TABLE 1: CHEMICAL COMPOSITTON OF COWPEA HAY FED (G/100gDM).

\begin{tabular}{lc}
\hline Constituents & $(\%)$ \\
Dry Matter & 89.8 \\
Organic Matter & 81.1 \\
Crude Protein & 12.7 \\
Crude fibre & 18.5 \\
Ether extract & 1.8 \\
Nitrogen-free-extract & 48.1 \\
Ash & 6.7 \\
\hline
\end{tabular}

The data in water and feed utilization of the experimental goats in Table 2 indicate that the bucks offered $50 \%$ water above minimum water requirement (group B) consumed significantly $(P<0.05)$ higher amount of the roughage $96 \mathrm{~g} / \mathrm{W}^{0.75} \mathrm{~kg} /$ day than those on the minimum water requirement treatment $64 \mathrm{~g} / \mathrm{W}^{0.75} \mathrm{~kg} /$ day. Similarly the average daily water consumption of $352 \mathrm{ml} / \mathrm{W}^{0.75} \mathrm{~kg} /$ day for the group $B$ bucks was also higher than the value of $310 \mathrm{ml} / \mathrm{W}^{0.75} \mathrm{~kg} /$ day for the group $A$ goats. The higher DM intakes of the group B goats possibly necessitated the higher water consumption of the goats as a result of a greater need for water in digestion, utilization and elimination of the waste products of metabolism. Those observations are supported by the results of Phillips (1960) who outlined the significant role of water in the digestion and excretion of waste products of metabolism. Ikhatua and Olayiwole (1982) reported a decline in feed intake of feedlot animals as a result of reduction in water intake by the animals.

A positive correlation between water intake and feed intake was observed in this study with correlation coefficient ( $\mathrm{r}$ ) values of 0.47 and 0.53 for the two groups respectively. This result is in conformity with the works of Philips (1960), Roubicek (1969); Devendra and McIlroy (1982). The dry matter (DM) to water intake ratios of 0.21 to 0.27 for the groups are similar to the range 0.20 to 0.25 reported by Devendra and McIlroy (1982) for goats in the tropics.

Although there was a significantly $(\mathbf{P}<0.05)$ higher nitrogen intake by group $B$ goats, the amount of nitrogen retained as per cent of nitrogen intake were however similar in both groups. This result is possibly due to the significantly higher amount of nitrogen loss by the group $B$ goats through nitrogen metabolism as a result of the higher water intake. This trend in the nitrogen loss of the experimental goats agrees with the findings of Utley, Bradley and Boling (1970) and Thornton and Yates (1968). 
TABLE 2: PERFOKMANCE OF EXPERIMENTAL GOATS

\begin{tabular}{lccc}
\hline \multicolumn{1}{c}{ Parameters } & \multicolumn{3}{c}{ GROUPS } \\
& & & \\
\hline & A & B & S.e.m \\
Mean liveweight $\left(\mathrm{Wkg}^{0.75}\right.$ ) & 6.6 & 7.5 & 0.80 \\
Mean daily liveweight gain (g/Wkg $\left.{ }^{0.75} / \mathrm{day}\right)$ & 36.0 & 55.0 & $1.9^{* *}$ \\
Mean DM intake $\left(\mathrm{g} / \mathrm{Wkg}^{0.75} / \mathrm{day}\right)$ & 64.0 & 96.0 & $2.2^{* *}$ \\
Efficiency of food utilization $(\mathrm{kg}$ feed/kg gain) & 1.0 & 1.7 & 8.03 \\
Mean water intake ml/Wkg.75/day) & 31.0 & 35.2 & $1.04^{\text {n.s }}$ \\
Dm intake: Water intake ratio & 0.21 & 0.27 & 0.06 \\
Nitrogen Metabolism (g/Wkg ${ }^{0.75} /$ day) Nitrogen intake & 0.77 & 1.16 & $0.24^{* *}$ \\
Nitrogen loss (faecal + urinary) & 0.48 & 0.69 & $0.18^{* *}$ \\
Retained Nitrogen & 0.29 & 0.47 & $0.09^{* *}$ \\
Apparent digested Nitrogen (\%) & 57.8 & 68.6 & $1.16^{* *}$ \\
N-retained as \% N-intake & 37.7 & 40.5 & n.s \\
& & & \\
\hline
\end{tabular}

*Mean between groups are statistically different $(\mathrm{P}<0.05)$

A significantly higher average daily liveweight gain was recorded for the group B goats. This may be partly due to the higher feed intake and nutrient, particularly the protein, utilization by this group of goals. The experimental goats being weaners would utilize nutrient efficiently for growth. This is similar to the findings of Umunna et al. (1981). Feed efficiency was however very similar in both groups of experimental goats.

The apparent digestion coefficionts given in Table 3 indicate that except for crude fibre

TABLE 3. APPARENT DIGESTION COEFFI. CIENTS (\%) OF COWPEA HAY FED

\begin{tabular}{llcl}
\hline Nutrients & \multicolumn{3}{c}{ GROUPS } \\
& A & B & S.e.m. \\
& & & \\
\hline Dry Matter & 49.62 & 61.2 & $2.4^{\text {** }}$ \\
Crude protein & 57.80 & 68.6 & $1.6^{* *}$ \\
Crude fibre & 54.6 & 58.4 & $0.8^{\text {ns }}$ \\
Nitrogen-free-extract & 64.3 & 71.7 & 1.4 \\
Ether-extract & 58.8 & 62.3 & $0.9^{\text {ns }}$ \\
& & & \\
\hline
\end{tabular}

**Values are significantly different $(\mathrm{P}<0.05)$ between the groups. and ether extract (fat), the group B bucks were significantly more efficient in digesting the nutrients of the roughage than the group A bucks. This is perhaps attributable to the higher water consumption of the animals in this group. This is similar to the results of Ikhatua, Ehoche and Umoh (1985) in which a progressive higher nutrient digestibilities were observed between free choice and water restricted Zebu bulls. This higher nutrient utilization perhaps explained in part the significantly higher DM intake also observed with this group of goats. The higher nutrient digestibilities of this group of goats allowed a rapid passage of the nutrients through the gastro intestinal tract, creating more intake to achieve maximum 'rumen file'.

\section{ACKNOWLEDGEMENT}

The authors are grateful to the University Research and Publication Committee for providing funds for this study. We are also grateful to the Farm workers especially Mallam Aminu for managing the animals

The permission of the Farm Management Board to carry out the study is also acknowledged. 


\section{REFERENCES}

A.O.A.C. 1980. Official Methods of Analysis. 13th Editon. Association of Official Analytical Chemicals, Washington D.C.

\section{AGRICULTURAL RESEARCH COUNCIL,} 1965. Nutrient requirements of goats; Water requirements In: Goat and Sheep Production in the Tropics. 1st edition, Longman, London.

DEVENDRA; C. and Mcllroy, G. B. 1980. Nutrient Requirements of goats; Water requirements In: Goat and Sheep Production in the Tropics. 1st edition, Longman, London.

IKHATUA, U. J.; and OLUBAJO, F. O. 1979. Studies on protein requirements of steers $I$. Nitrogen balance studies with three breeds of cattle maintained on all roughage diets. East Africa Agric and Forestry J. 44(4): 272-277.

IKHATUA, U. J.; and OLAYIWOLE, M. B. 1982. Seasonal effects on performance of feedlot bulls. J. Anim. Prod. Research 2(2) 99 - 111.

IKHATUA, U. J.; and ADU, I. F. 1984. A comparative evaluation of the utilization of groundnut haulms and Digitaria hay by

Red Sokoto (Maradi) goats. J. Anim. Prod. Research 4(2):145-152.

IKHATUA, U. J.; EHOCHE, O. W.; and UMOH, J. E. 1985 . Effects of restricted water on feed intake, nutrient utilization and nitrogen metabolism in Zebu cattle. J. Agric. Science. (Camb.) 105(2): 463-467.

KING, J. M.; NYAMORA, P. O.; STANLEYPRINCE, M. R.; and HEALTH, $R$. L.; 1978. Game domestication for
Animal Production in Kenya. Production of Water intake from tritiated water turnover. J. Agric. Sci. (Camb) 911: 513-522.

McFARLANE, W. V.; and HOWARD, B. 1972. Comparative water and energy economy of wild and domestic animals. Symposium Zool. Society. London, 31: 261-296.

PHILIPS, G. D. 1960. The relationship between water and feed intakes of European at Zebu type steers. $J$. Agric. Science 54: 231-234.

PRESTON, T. R. and LENG, R. A. 1987.

Matching Ruminant Production Systems with available resources in the tropics and sub-tropics. Penambul books, Armidale, Australia pp.

ROUBICEK, C. B. 1969. Water Metabolism. In: Animal Growth and Nutrition. E. S. E. Hafez and I. A. Dyer (eds). Lea and Febiger, Philadephia, pp. 353-373.

SINGH, N. F., MORE, T. and SAHNI, K. L. 1976. Effect of water deprivation on feed intake, nutrient digestibility and nitrogen retention in sheep. J. Agric. Science 86: 431-433.

STEEL, R. G. D. and TORRIE, J. H. 1960. Principles and Procedures of Statistics. new York, Toronto and London. McGraw Hill Book. Company.

THORNTON, R. F. and YATES, N. G. 1968. Some effects of water restriction on apparent digestibility and water excretion of cattle. Australian J. Agric. Res. 19: 665-672.

UMUNNA, N. N., CHINEME, C. N.,SAROR, D., AHMED, A. I. and ABED, S. 1981. Response of Yankasa sheep for 
various lengths of water deprivation. J. Agric. Science (Camb) 96(2): 619. 622.

UTLEY, P. R., BRADLEY, N. W. and BALING, J. A. 1970 . Effects of restricted water intake on feed intake, nutrient digestibility and nitrogen metabolism in steers. J. Nutrition 100: 551-556.
WHYTE, R. O. 1963. "Milk Production in Developing Countries". Faber and Faber Ltd., London. pp. 83-86.

WILLIAM, C. and PAYNE, W. J. A. 1984. An Introduction to Animal Husbandry in the Tropics. 3rd edition, Longman London. pp.134-145. 